\title{
Professional Confusion and Intervention of Teachers in Private Universities
}

\author{
Miaona You 1,a, Ruxue Luo,b, \\ ${ }^{1}$ Guangdong Ocean University Cunjin College,Zhanjiang,Guangdong,China \\ ${ }^{2}$ Guangdong Ocean University Cunjin College,Zhanjiang,Guangdong,China \\ auna168@163.com, b651602273@qq.com \\ ${ }^{*}$ Corresponding author
}

Key words: Teachers in private universities, Professional confusion,Intervention.

\begin{abstract}
The private universities have become an important part in the universities of our country, and a large number of private school teachers are significantly different from the characteristics of the public school teachers. The initiative and product quality of the private college teachers are directly related to the teaching level and the teaching effect. The professional confusion of teachers in private universities mainly appears in several aspects, such as heavy work tasks, low job security, low salary treatment, poor social status, narrow personal development space and poor scientific research environment, and lack of communication, and finally put forward to intervene from three aspects: society, school and teacher.
\end{abstract}

\section{Introduction}

College teachers not only have the professional characteristics of ordinary teachers, but more importantly, they have been endowed with unique professional characteristics in the new era. These characteristics are mainly manifested through personality traits, professional labor characteristics and personal qualities. In China's higher education system, private universities are an important part, and private universities also occupy an important position, which will become more and more important and play an important role.

However, the private teachers should be one of the special groups, from the universality of the teachers in the public universities to explore the professional situation of the teachers in private universities, which make more sense.

\section{Question}

Confusion is a reflection of a person's state of mind, a process that does not develop over time. After that, the study of confusion and confusion has been deepened, and the concept of confusion and the subject of study have gradually expanded to the education profession

With the development and expansion of private universities, the teachers of private colleges have formed a large group, the current domestic study of private university teachers' professional development characteristics is mainly manifested in four aspects.

First, from the perspective of teacher career development, we systematically study the confusion of teachers in private colleges in professional process.

Second, the study of professional confusion of private college teachers, with the deepening of the research, the study also gradually in-depth and detailed, from different gender, different degree, different types of school teacher's point of view for research.

Third, through a large number of research, the course of the study was carried out by a large number of empirical studies, the study also from the past mainly on qualitative research to the present stage of combining qualitative and quantitative research. It has accumulated a lot of empirical data for the study of teaching profession.

Fourth, the localization trend of research on teacher's career perplexity is continuously 
strengthened, many studies are based on job burnout western thoughts, combined with China's education (including public and private education) of general and specific environment for teacher career perplexity problem for study.

\section{Professional perplexity index of teachers in private universities.}

Through investigation and interviews with experts, it is concluded that the following aspects may cause the burnout of teachers in private universities: low sense of security and psychological pressure; heavy duty; unreasonable position competition mechanism; low pay; emotional fatigue; lack of a textual concern; poor social status; narrow personal development space; poor research environment, lack of communication and strict management system. However, after the investigation and interview of the teachers in private colleges, the main factors mainly reflected in the heavy work tasks, psychological pressure, low occupational safety; low pay; poor social status; the lack of personal development space and poor research environment and lack of communication.

\subsection{Heavy work tasks}

According to current education policy and regulations in our country, private higher schools in accordance with the school system, operation mechanism of private colleges, however, because of its nature, all funds and resources involved in running a school shall be raised by the organizer itself. The organizer of private universities mainly invest their own funds and adopt the method of "school for school". Under the premise of consideration of cost, the organizer has adopted more cost control measures in terms of the cost savings: the recruitment of professional teachers in private universities and the training of skills development. And under the premise of considering the cost control, private colleges will not like public universities to take the need of teaching as a complete starting point to configure the teachers, so the number of private colleges' full-time professional teacher allocation is insufficient. Therefore, it is inevitable that the teachers of private universities have a large workload and high pressure.

In the survey, we found that mostly in private colleges, a full-time professional teacher's weekly hours more than 15 classes, which are very common, and each semester often more than three courses. The teachers working in private colleges spend a lot of time for preparing, taking class and correcting students' papers, makes the high teaching workload and high intensity of the super negative effect of private college teachers. All of these result in the teachers' physical exhaustion, when compared with that of teachers in public colleges and universities, may lead to emotional outbursts and a decline in productivity, these confusions will seriously affects the work efficiency of teachers in private universities, it is also one of the working perplexity of the teachers in private colleges.

\subsection{Low job security}

According to Maslow's demand theory, a person's most basic need is security. First, private higher education is still in the extensive stage of China's private universities education. The education and management system is not perfect enough, management is far from being required, and private colleges cannot like universities to give teachers security, so that the private teachers in private colleges produce a feeling of instability. Secondly, because of the characteristics of the source of funds in private universities, the teachers' compensation level is generally relatively low. Third, the gap of welfare between the private and public colleges is large. According to these factors, private college teachers produce different degree of anxiety and panic, reduce the sense of security and belonging, it's difficult to allow teachers to devote to work.

On the other hand, due to the private nature of private colleges, it can only be in the form of contract to adopt appointment system. In the management process, teachers will probably be lowered level, even guard relieved. If serious they may lose the job, which makes the private 
college teachers produce occupational stress, so that the teachers have bad feelings of low job security. Private colleges usually adopt a strict teacher assessment, even the elimination. Even though the purpose of private colleges is teaching quality and social reputation, the private college teachers are hard to focus on their work. Under the condition of constant high pressure, the probability that a teacher may have career confusion is certainly significant.

\subsection{Low remuneration}

The running funds of private colleges mainly come from the folk capital and tuition income. Compared with universities, the development of private colleges has been affected and restricted by limited funding and poor stability. Private colleges in our country are often at a disadvantage in the competition. In particular, it is more prominent in the competition with foreign education institutions with deep pockets and public universities.

At present, there are many problems in the salary management of private universities in China. In general, the salary structure and positioning of private colleges are unscientific and unclear. Compensation management lack of normative and sustainability, especially salary management has the randomness, and compensation technology lags behind, etc. This reflects the performance salary system is not perfect in private universities. But the main reason is because of limited funds run by the local colleges and universities, private universities did not attach enough importance to teachers, there are many factors such as graduate degree, led to the private colleges teachers after the rated work completed (typically workload is one of the three points above than public colleges and universities), the income is generally to the corresponding state teacher's salary is low, it is easy to cause run by the local college teachers' occupational burnout.

\subsection{Poor social status}

The transformation from the elite education to the popular education, this is a practical experience in the development of education in China. High school level, good social reputation, and good social education environment, these are the social systems in our country that are given to public universities. Under the condition of good resources, the public universities have good running income, and obtain the popular recognition and affirmation.

But the development time of private universities is relatively short, in our country higher education system, private colleges still in a relatively weak and even on the edge of the state, so that the economic strength of running or managerial ability and quality, there is a huge gap compared with public colleges and universities. These factors, is bound to make the social status of private colleges lower than that of public colleges. Even in the society, the teachers in private universities dare not positive answer is working at a private university. This is also because public universities in the public's education identity, while private universities have lower social status. Because of the poor social status of teachers in private colleges, the teachers are gradually becoming tired.

\subsection{Narrow personal development space}

Colleges and universities are not only the places where teachers work, but also the main organizers and the development strategies of the teachers in the process of teacher development, so as to play the guiding and stimulating role of the development of teachers. Especially in private colleges, the importance of teacher development, as the leader of private colleges should have a clear understanding, whether it is a policy support, or give the system security. If we want to achieve the development of teachers scientifically, we should also carry out proper analysis, diagnosis and evaluation of the development problems.

Teachers' participation in all kinds of training education is an important way for teachers to improve and develop themselves, so that teachers have good personal development space. Public colleges and universities have plenty of funds and resources, can provide a good development space 
for teachers. But due to handling and limited resources, private colleges hard to provide adequate space for teachers and develop teachers, difficult to promote and stimulate the development of private college teacher power, the development of private colleges teachers in their own personal development space to appear on the narrow, which makes private colleges teachers' job burnout.

\subsection{Poor research environment and lack of communication}

The newly graduated master's and the retired professors of public universities are the main sources of teachers in private universities. The students who just graduated are the majority, and teaching experienced core teachers and doctors will not voluntarily enter the private universities. And private colleges to teacher' s evaluation are mainly the evaluation of teachers' teaching ability, which does not involve scientific research ability and achievements. This is the key factor for teachers' poor research environment. Another factor is that the research funding of private universities is basically little input or no input, which makes the teacher's research neither pressure nor motivation. However, the scientific research results are the most important criteria for the professional title evaluation of teachers, this led to the private college teachers' scientific research ability is difficult to ascend, and the professional titles are difficult to promote. Individual teachers' scientific research can only carry out in the large workload and poor scientific research environment, the level of achievement is low and the difficulty is high. In this case, only a small proportion of the capable and highly skilled teachers through their own efforts to upward mobility. Some of the teachers admitted to a doctoral degree, the other pass the examination of civil servants. Some lower-level teachers are unable to leave. With the loss of highly qualified teachers in private colleges, it has become a training base for young teachers. Due to poor scientific research environment and insufficient research funding, scientific research team also difficult to form. Teachers with scientific research ideas can only work without the support of the team. They can only get some low-grade scientific research projects, and the scientific research achievements are not high.

The private colleges consider saving cost, they rarely spend money on the promotion of teaching level. And as a result of the limitation of funding, the school also will not send teachers out for further study or academic exchanges, this will affect the improvement of teachers, teachers gradually appeared confused.

\section{Intervention countermeasures for the perplexity of teachers in private universities}

From the above analysis, we know that private colleges teachers' career confusion mainly appear in the hard work task, low job security, low salary, poor social status superiority, narrow personal development space, poor scientific research environment and lack of communication. Intervention countermeasures from three aspects: society, school and teacher.

\subsection{Social support}

We should deeply understand the importance and particularity of private colleges in our country for higher education, first we should fully understand the characteristics of private education in colleges and universities in China, and this is of great significance to the development of education.

Our society needs experts with theoretical literacy, private colleges education is generally focused on the cultivation of applied talents, because of the practical need of society development, the development of education in private universities should focus on the cultivation of applied talents. Applied skilled personnel should have the corresponding theoretical knowledge and professional skills. Therefore, we should publicize the importance of private higher education through the media; publicize the social value of teachers' work in private universities to change the phenomenon that discriminates against the higher education teachers. To make private colleges teachers to truly love their profession, we need to work from the perspective of social status and professional identity, and the improvement of social status and professional identity is not one-sided. 
It requires the efforts of the school and the participation of teachers. As a teacher, we should also strive to improve our skills of practical education and the application of vocational, so that teachers can be enhanced either in self-esteem or work pleasure or in self-actualization.

\subsection{Support from school}

In the development of private colleges education, the key is that leaders attach importance to teachers. We can't think that there are so many graduate students now that we can easily recruit teachers, rather than the stability of teachers. This will lower the teachers' sense of belonging, even have no sense of belonging, and make private colleges teachers' job burnout. The private universities should also provide more convenient conditions for the personal improvement and professional title evaluation, to promote the growth of private universities.

Teaching type and application type have became the first big feature of all private colleges basically. As a result of the limitation of capital investment and the increase in student enrollment, the workload of teachers is almost double the workload of public colleges teachers, which may be more. So the private colleges teaching work is too hard, and poor academic atmosphere, limit the growth of teachers. Therefore, we should take the initiative to reduce the burden on teachers, increase the input of resources, create a good academic environment, and let teachers actively integrate into and become masters of private universities. This will definitely enhance the private college teachers working mood of a strong support.

\subsection{Personal efforts of teachers}

We should not only recognize the significance of ourselves as a university teacher, but also realize that the profession of teachers has a good development prospect. In particular, as a teacher, it is also responsible for carrying forward advanced culture and teaching advanced productive forces. We should correctly understand the professional status and nature of the teachers in colleges and universities, and constantly strengthen their professional identity and self-adjustment ability. In the working process we should affirm ourselves, for some social prejudice, we should have some thought preparation and method preparation. Relying on our own efforts, in the course of teaching, pay attention to the practical effect, pay attention to further master professional theoretical knowledge and professional practical skills, teach through lively activities and make an achievement.

In the process of teacher development, private universities should constantly arouse teachers' sense of achievement and create a positive working atmosphere. Constantly improve the teacher's self-confidence, and let the teachers have a positive attitude in the work process. The school also needs to provide various opportunities to show the teachers' abilities and achievements, which will not only improve the sense of belonging and social status of teachers.

\section{Summary}

To make private universities have a good development situation, the premise is the healthy development of the teachers. The healthy development of the teachers' team is the premise of the good and orderly development of education activities in private universities. Only through different channels to carry out teaching activities effectively and constantly inspire teachers' vocational interest, improve teachers' work enthusiasm and avoid private college teachers' job burnout, to promote the improvement of education quality. It is a necessary condition to comprehensively improve the education benefit and quality of private universities.

\section{Acknowledgement}

Guangdong financing project in 2016: Innovative school project--comprehensive reform pilot of 
business administration. (No. cjxy201617008)

\section{References}

[1] W. zhiwei,Discussion on optimizing the model of scientific research and management in Universities, Scienceand Technology Management Research,vol.12,pp.89-93,2010.

[2] Y. qili,A brief discussion on the development strategy of College Teachers,HeilongjiangResearchesonHigherEducation,vol.10,pp. 115-117,2007.

[3] M. shuangwei,Causes and intervention strategies of teachers' job burnout in Higher Vocational Colleges,Vocational time and space,vol.12,pp.150-151, 2009.

[4] F. Anguo,D. Jun,W. Na,The Investigation and Analysis on the Circumstance of the University Teachers' Job Burnout and Its Countermeasures,Journal of Beijing Institute of Education(Natural Science Edition),vol.2,pp.12-17, 2011. 